\title{
On the Three-method \& Two-way Guarantee System in the Cultivation of Tourist Talents Through Cooperating Between College and Enterprises
}

\author{
Dehui Kong ${ }^{1, \text { a }}$ \\ Heilongjiang University of Technology, Zip code 158100, China \\ 16107421@qq.com
}

Keywords: Personnel training; school enterprise cooperation; Three-method \& Two-way

\begin{abstract}
On the construction of system for school enterprise cooperation in "Three-method \& Two-way", which is take the flexible ways in the process. To achieve full depth of cooperation in the depth of integration, improve the incentive and training mechanisms, the enthusiasm and guidance of practical ability of teachers. The cooperation will improve the students adaptability, creativity and learning ability in enterprise and guidance of school enterprise cooperation with comprehensive, systematic and scientific ways through the whole process management method of "PDCA" in practice of supervision and guidance. To training excellent tourism talents with strong innovation and adaptability.
\end{abstract}

\section{Introduction}

Deepening School enterprise cooperation is the only way which is to training high-quality applied talents, enhance the ability of service in school, regional economic development and improve the level of talent training. The three-method \& two-way guarantee system is based on the school enterprise cooperation and win-win. The training mode is open, interdependent and mutually promoted by the parties in the form of agreement that is a new form, which has injected new vitality into the teaching reform of higher education, and provides a scientific and sustainable model for the cultivation of tourism in universities, can guide other professional personnel cultivation, will be widely adopted by universities and enterprises, help the development of enterprises and train more talents for society.

\section{The Necessity of Constructing the Three-method \& Two-way Guarantee System Between College and Enterprises}

The tourism professional carried out school enterprise cooperation in colleges and universities for many years was aimed at arrange the student graduation practice through the establishment of the practice base and order form training and so on. Some enterprises put forward some suggestions and feedback according to professional curriculum setting and personnel training program that the students has got the skill and experience, some teachers has got the practice of the ability to exercise in the process of school enterprise cooperation. But in the new situation of the school enterprise cooperation for the training of applied tourism personnel, need for a comprehensive thinking. The college and university should be set up according to the demand of tourism enterprises, tourism industry enterprises should participate in the process of tourism personnel training including the provision of practice places and teachers. The tourism business continuity recieve trainees(graduates) to give guidance and cultivation and to evaluation the process of personnel training. Simply said that the application of tourism personnel training is generated from the enterprise (there is demand and the demand for talent), in the platform of school and enterprise grow together and to the enterprise (reception and testing). It is shows that the cooperation is a all-round, the whole process and full participation of school and enterprise. Whether the school enterprise cooperation is appropriate and in place will directly affect the quality of the training of applied talents. Appropriate, it is said that the choice of the right enterprise; in place, is to say that policy, personnel, mechanism, process management, the results of the evaluation to do in place. 
The system of three-method \& two-way guarantee cooperating between college and enterprises after the completion of professional basic courses for students, and arrangement practice of enterprise for students and combine the theoretical knowledge with the actual operation. Both the school enterprise cooperation are the main bearer of the talent training, the role of the enterprise from the auxiliary, adjust to the same important role as the school. The system of three-method \& two-way cooperating between college and enterprises make guarantee as three-method \& two-way through the full range of cooperation, the participation of all teachers and students, the whole process of supervision and guidance, to achieve enterprise development, school personnel training and win-win。

\section{All-round, the whole process and full participation for guarantee system of cooperating between college and enterprise}

Industry enterprise need for tourism personnel. First, tourism personnel training in line with the needs of industry enterprises, to adapt to the industry enterprises, can bring value to the enterprise. Enterprise is the main body of the evaluation of the effectiveness of personnel training, industry enterprises is the source, but also the end. The development of industry enterprises can not be separated from talent support, tourism personnel training work can not be separated from the industry enterprises, industry enterprises should be an important driving force for tourism education and teaching reform.

Combined with the actual situation of regional social and economic development, select the right enterprise. The institution of higher learning and the industry enterprise should achieve the integration of all-round and gapless, bring enterprise into the process of training for tourism talent. First of all, the industry should strengthen the forecast of talent demand, establishment standards of talents, publish the employment situation regularly. Second, enterprises should participate in the curriculum reform, carry out quality evaluation, and provide guidance and support for talent training and teaching reform. Third, encourage enterprises to fully participate in the whole process of school governance, management and operation, support enterprises to participate in school, professional custom, exploring the model of accept vocational training in enterprise and he theory of learning in school, working together to develop course materials, professional and technical personnel exchange, carry out joint research and build technology centers, training base and practice training base. Finally, enterprises should fulfill their social responsibilities to support students' training and teachers' practice, support enterprise management and professional technical personnel to do part-time job in cooperative department and support technology and knowledge sharing on the basis of mutual benefit.

The biggest characteristicses of school enterprise cooperation for the training of applied tourism personnel is combined with the actual development of local tourism economy, the first is choose cooperation object. Taking an example of department of economics and management, Heilongjiang Institute of Technology, the school located in Jixi City, Heilongjiang Province, regional economic underdevelopment and it's difficult to carry out cooperation of tourism management. Combined with the actual situation, the specific approach is: enterprises generated from school (school training base), the selection of local suitable enterprises, make the well-known enterprise stable.

(1) Construction Training Hotel on Campus. As a small service enterprise with the ability to receive, Training hotel covers procurement, finance, accounting, personnel management, material management, marketing and business management, and other aspects of the content with comprehensive training function in the professional of economic management.

(2) Establishment tourism management consulting company. Taking the senior teachers as the main body of tourism, promoting the participation of young teachers and students' practice and employment. Management content mainly has the analysis of the tourism industry, travel agency business agent, the hotel enterprise diagnosis and consultation, tourism industry training, etc..

(3) Cooperation with local tourism enterprises in depth. To carry out further work from many aspects such as Five Star Hotel, international travel agencies and other tourism enterprises from the 
talent specifications, curriculum, practice teaching platform, teacher exchange, foreign training, etc. achieving the cooperation between colleges and enterprises effectively

(4) Contact with the famous foreign enterprises and deepen the cooperation between enterprises and enterprises. Foreign enterprises should choose a higher popularity, standard management, enterprise culture healthy and progressive, the student feedback is excellent, especially attach importance to internship management and enterprise collaboration with schools.

"Four models" and "six integration" of the full depth of integration in school and enterprise, promote "win-win" of cooperation in school and enterprise. The cooperation of school and enterprise in order to achieve flexible personnel training using a variety of ways and reached a cooperation agreement with enterprise on the basis of "win-win". The combination of content in different ways and professional courses, such as the combination of the way, depth, etc. Especially to take into account the depth of integration with the development of enterprises.

"Four models" is the model of four school enterprise cooperation : in cooperation with enterprises to build a professional in order to train professional and technical personnel, such as naming certain classes of enterprise. The co-sponsoring to training practical talents, construction of training basement for training compound talents and international cooperation in the training of international talents in order to form a three-dimensional cooperation, training all kinds of talents
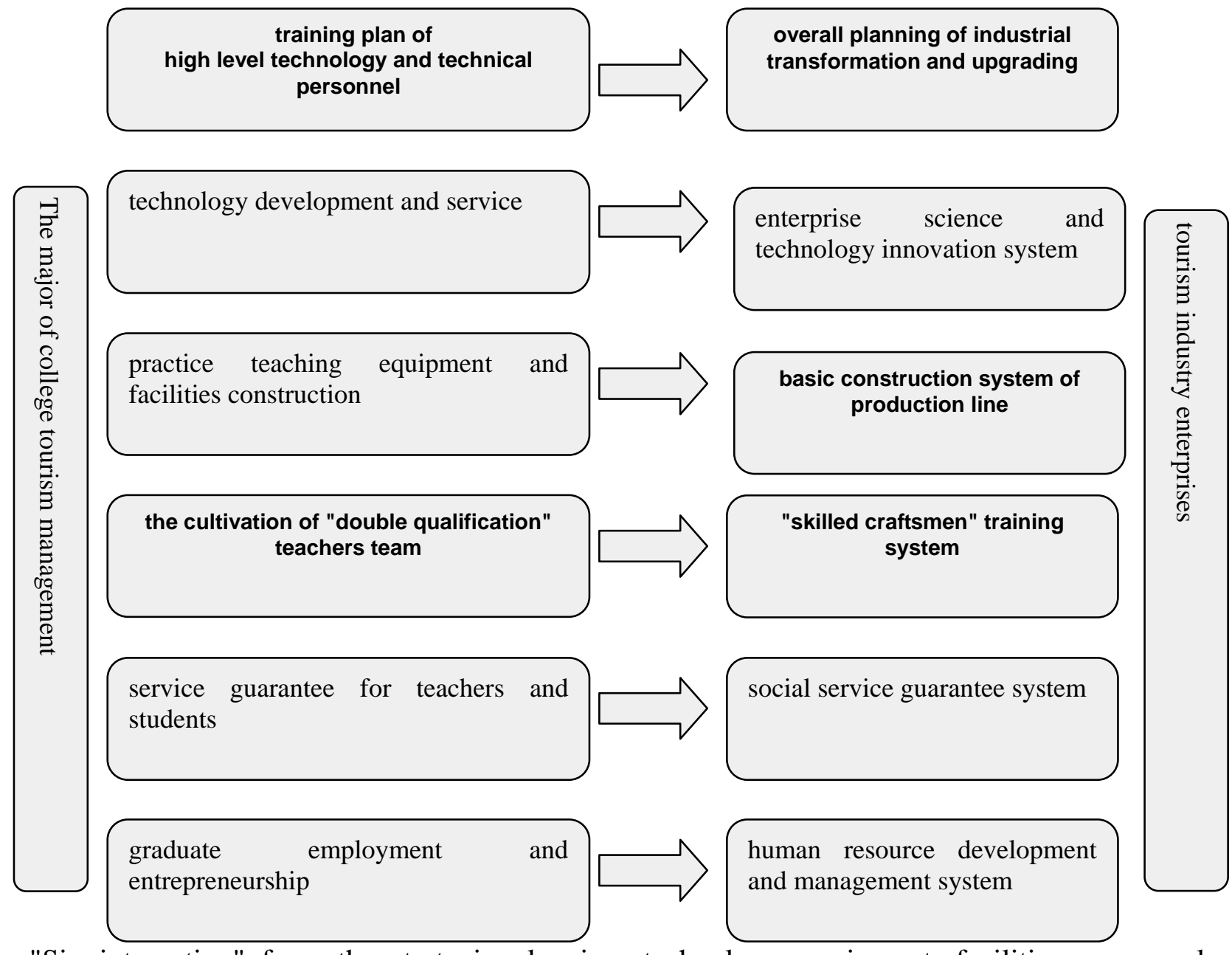

"Six integration" from the strategic planning, technology, equipment, facilities, personnel, security, future development and other aspects of the in-depth integration of industry enterprises. The transformation of talent training goal and industrial in local colleges and Universities which is consistent of the overall plan for the provincial level of talent demand. The technology services and patent development of universities and so on should not only be linked to the application of the enterprise, but it's best to be based on enterprise technology innovation. In the laboratory, training center and other equipment and facilities of school, the actual production of enterprise is consistent, 
narrowing the distance between the students and the job. The "double teachers (double title type and double quality type)" and enterprises "skilled craftsmen" can mutually used by school. When students go to practice, involve in treatment, insurance and other issues, should be regarded as the labor force into the social insurance system. Government departments such as the local employment bureau, after graduation, no matter employment or entrepreneurship, the government will provide recommendations and guidance, the establishment of archives for local talent development and reserves to do work.

A variety of ways to mobilize the enthusiasm of teachers, to achieve the full participation of teachers and students in school enterprise cooperation. The main implementation of the school enterprise cooperation is a professional teacher, need to participate in the whole process of professional teachers. Otherwise, even if the school signed a good business, no one to carry out the work, it's just formality. First, improve the enthusiasm of teachers to participate in school enterprise cooperation. Although the teacher can improve the teaching ability through the cooperation between school and enterprise, but it will not bring about improvements in recent, significant benefits. On the contrary, it will occupy the individual research and leisure time and impact of the promotion and salary. So the teachers' enthusiasm will not be very high. If we want to implement the school enterprise cooperation, we must work out the corresponding incentive and security mechanism.

(1) Compensation points: Teachers participating in school enterprise cooperation, a semester to compensate ** points, for example, the equivalent of paper scores for national core journal.

(2) Project priority: Teachers participating in school enterprise cooperation, a professional team is carried out the research of teaching reform with the cooperation of school and enterprise as the content, have priority to recommended provincial projects.

(3) Equal rights: The teacher take excercise to enterprise and guiding students practice depth into enterprise, enjoy the same performance standards as teachers in the school.

(4) For teachers who do not participate in school enterprise cooperation to carry out a certain punishment

Only to dispel the concerns of teachers to pay the cost of transformation, giving the hope of career development, in order to mobilize the enthusiasm of professional teachers to transform, enhance their practical ability.

"PDCA" cycle supervision the whole process of the school enterprise cooperation. School enterprise cooperation is a complete working process from the plan (Plan) --- the organization to implement (Do) --- check (Check) --- feedback adjustment (Action). Every time after a PDCA cycle, the level of personnel training to raise a level, the teachers are the main body in each link . 


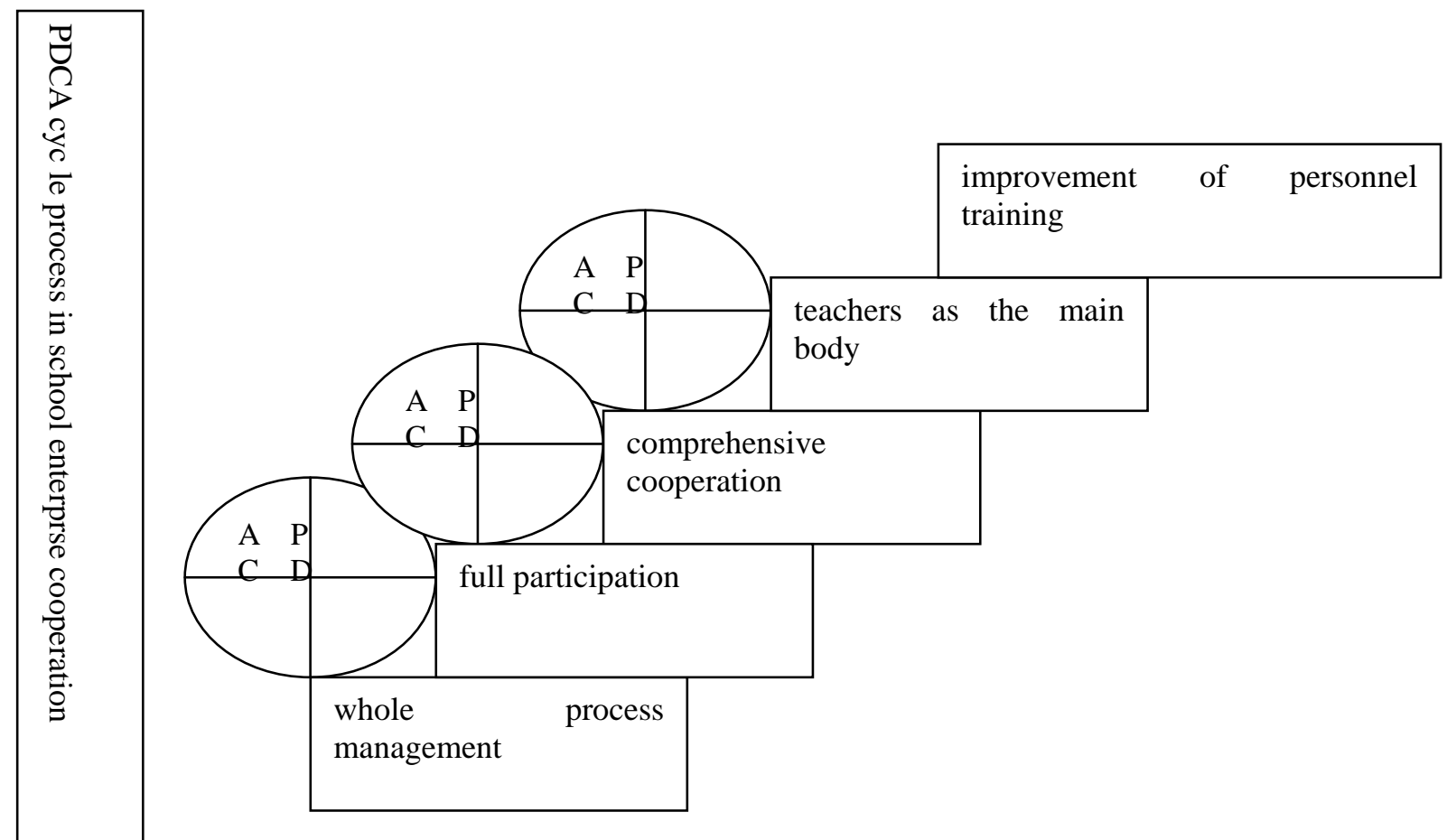

The "PDCA" process management of school enterprise cooperation with the teacher as the main body

Specific content and requirements in process of PDCA cycle:

P-plan: To carry out of "school enterprise cooperation work approach". The work approach carry out the requirements and norms, the reward and punishment system, work processes and standards, the results of the assessment and evaluation methods in cooperation between colleges and enterprises. Work out of tourism professional "school enterprise cooperation plan". Plans must have maneuverability, have target enterprise (1-2), if not, must have methods and plans of the enterprise development, specific and feasible cooperative content (manner, how to and curriculum were tandem fusion), make sure process of school enterprise cooperation and links, each link (or curriculum) provision the main person in charge, the implementation of the time node and work objectives, work content.

D - organization implementation: According to tourism professional "school enterprise cooperation plan", establishment organization of tourism professional in school enterprise cooperation , make sure the work tasks and objectives,to carry out various forms of work in various forms .

C-check: To male sure of the supervisory personnel, responsible for the process of inspection the school enterprise cooperation ,supervision and guidance of professional teachers in the practice of school enterprise cooperation, to help them solve problems.

A - Feedback and adjustment: Evaluation and feedback of the achievements of cooperation between school and enterprise. The school enterprise cooperation is reporting on the development of school enterprise cooperation for the monthly, quarterly and term periodic. Sum up experience and lessons, and put forward the adjust the program for next step, and carry on the examination of the professional school enterprise cooperation.

\section{Shool teachers and off campus enterprises" of school enterprise cooperation and security system}

The professional teachers in the school are the implementation of tourism personnel training and teaching reform, bear the important role of the launch, guidance, management, connection in the school enterprise cooperation. Play the main role of teachers, so that school teachers to become the key to the application of innovative tourism talents, is the important content of the construction of 
enterprise cooperative security system. In the process of tourism personnel training for teachers to strengthen the training and exchange of cooperation between school and enterprise , lecture on school enterprise cooperation once a month, the exchange of activities to discuss the professional school enterprise cooperation every week. Through training, not only make the teacher made it clear how to proceed with the school enterprise cooperation, more important is to make the teachers practical with enterprise rather than in school, will to improve their ability of communication, and gradually improve the ability to combined knowlege and practical with practical guidance.

Enterprises are updating fast, new types of enterprises are emerging, which is both an opportunity and a challenge under the current era. An important way to improve the training level of tourism talents is close contact with the industry enterprises and seize the opportunity of enterprise. Tourism professionals should keep close contact with enterprises, broaden cooperation between schools and enterprises, and strengthen communication with the various departments of the school, especially is more effective between the school leadership and enterprise dialogue. School need to strengthen ties with government departments and led by government and docking with the enterprise, or cooperation with the government; and direct contact with the department of large enterprises to achieve a win-win and further cooperation through external training and arrange internships, etc.

School enterprise cooperation is an important way to training talents with ability of innovative, and it is also the only way to reform and improve the quality of personnel training in Colleges and universities. Construction of school enterprise cooperation system, achieve the win-win of school and enterprise tourism talents training. The system to guarantee the personnel training application of innovative. By changing the concept of the direction of the school enterprise cooperation, formulate the corresponding system plans, processes and standards to guide the specific work, establishment of organization personnel to ensure the realization of the target, establishment mechanism of training and exchange, finally through the all-round cooperation, full participation and whole process management mechanism of the school enterprise cooperation and make steady progress, to promote the cultivation of tourism talents.

\section{Reference:}

[1] K.Y. Chen, M.Y. Shu. Tourism Specialty in Higher Vocational College Students' post practice research and practice of fine management. Journal of Hubei TV University, January 2014.

[2] K.R. Yan. Difficulties and Countermeasures of the implementation of the excellent tourism professional talent training mode based on school enterprise cooperation, human resources, the first phase of 2014.

[3] S.Q. He. "School enterprise cooperation practice in Higher Vocational College, engineering development"analysis of personnel training mode. Journal of Kunming College of Metallurgy, the forth phase of 2009.

Source: Heilongjiang Province Institute of Higher Education

Name of Project: The deep integration of the "346" to promote the transformation and development of local colleges and Universities

Task categories: Youth special project

Project number: 14Q196 